\title{
ETÁN-ETILÉN SZÉTVÁLASZTó KOLONNA PARAMÉTERVIZSGÁLATA SZIMULÁCIÓVAL
}

\author{
Kállai Viktória - Szepesi L. Gábor
}

\begin{abstract}
Absztrakt: A vizsgálatban egy etán-etilén szétválasztó kolonna modelljét készítettük el Unisim Design szimulációs szoftverrel. A szeparálás célja az etilénben minél gazdagabb fejtermék kinyerése. A modell felállítása után paramétervizsgálatot végeztünk a rendszeren, amely során a betáplálás helyének, a reflux aránynak és a nyomásnak a változásaiból különböző következtetéseket vontunk le a fejtermék illetve a fenéktermék összetételét illetően. Továbbá vizsgálataink során kitértünk arra, hogy különböző fejtermék mennyiségeknél hogyan változik a termék összetétele.

A vizsgálatok elsödleges célja az volt, hogy egy optimális megoldást találjunk arra az esetre, hogy minél tisztább etilént kapjunk fejtermékként a leginkább energiahatékony módon.

Abstract: In the study, a model of an ethane-ethylene separation column was prepared using Unisim Design simulation software. The purpose of separation is to reach more concentration of ethylene in the overhead product. After the model was set up, a parameter analysis was performed on the system, with different conclusions from the changes the feed's stages, the reflux ratio and the pressure on the composition of the overhead and the bottom product. Furthermore, also investigated the overhead product-composition in case of different product quantities. The main goal of the research was to find an optimal solution in order to obtain the most ethylene mole fraction in the overhead product in an energy efficient way.
\end{abstract}

Kulcsszavak: etilén, etán, kolonna, betáplálás, moltört, reflux arány

Keywords: ethylene, ethane, column, feed, mole fraction, reflux ratio

\section{Bevezetés}

\subsection{A szétválasztás termékei}

Napjainkban az etán és az etilén a vegyipar elengedhetetlen termékei, számos -szinte nélkülözhetetlen - anyagot állítanak elő belölük. Például polimerizáció segítségével az etilénből különböző mủanyagipari termékek alapanyagát képező polietilént gyártanak. Míg az etán felhasználható fütési célokra, továbbá etilént is előállíthatnak belöle (Benali-Aydin, 2010).

$\mathrm{Az}$ olefin üzemek termékeként kinyert etilén további felhasználásánál meghatározó a minősége, ezért szükséges törekedni a legtisztább etilén fejtermék kihozatalra, és ezért ez a célja az elvégzett paramétervizsgálatnak. Az etilén és etán elválasztásnál a desztillációs technológia a legelterjedtebben alkalmazott szeparációs eljárás (Soave et al., 2006).

\subsection{Rektifikálás}

A betáplálás feletti felső oszloprész a dúsító vagy rektifikáló zóna, míg az alsó oszloprészt szegényítő vagy sztrippelő szekciónak nevezzük (Fonyó-Fábry, 1998). A kolonna teljes anyagmérlege:

$F=B+D$

Komponensmérlege:

$F x_{F}+B x_{B}=D x_{D}$

ahol 
$\mathrm{F}=$ betáplálás,

$\mathrm{B}=$ fenéktermék (maradék),

$\mathrm{D}=$ fejtermék (desztillátum),

$\mathrm{x}_{\mathrm{F}}=$ betáplált közeg moltörtje,

$\mathrm{X}_{\mathrm{D}}=$ desztillátum moltörtje,

$\mathrm{X}_{\mathrm{B}}=$ fenéktermék moltörtje. (Fonyó-Fábry, 1998)

Az etán-etilén egyensúlyi rendszer komponenseinek elválasztásához megfelelő mủvelet a rektifikálás (Fonyó-Fábry, 1998), mely során a rendszerből fejtermékként az illékonyabb komponens távozik - jelen esetben etánnal enyhén szennyezett etilén, fenéktermékként pedig kevés etiléntartalmú etán.

\section{1. ábra: Rektifikáló oszlop vázlata}

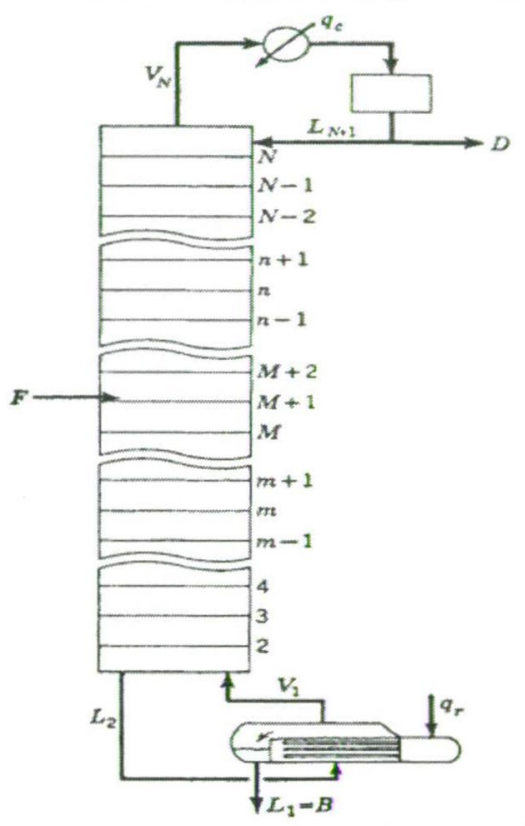

Forrás: Perry et al. (1997)

A 2. ábrán látható egyensúlyi görbe azt mutatja, hogy a két komponensnek nincs azeotrop pontja, tehát az elválasztás végbemehet, ideális az elegy (Fonyó-Fábry, 1998). 


\section{1. ábra: Etilén-etán egyensúlyi görbe}

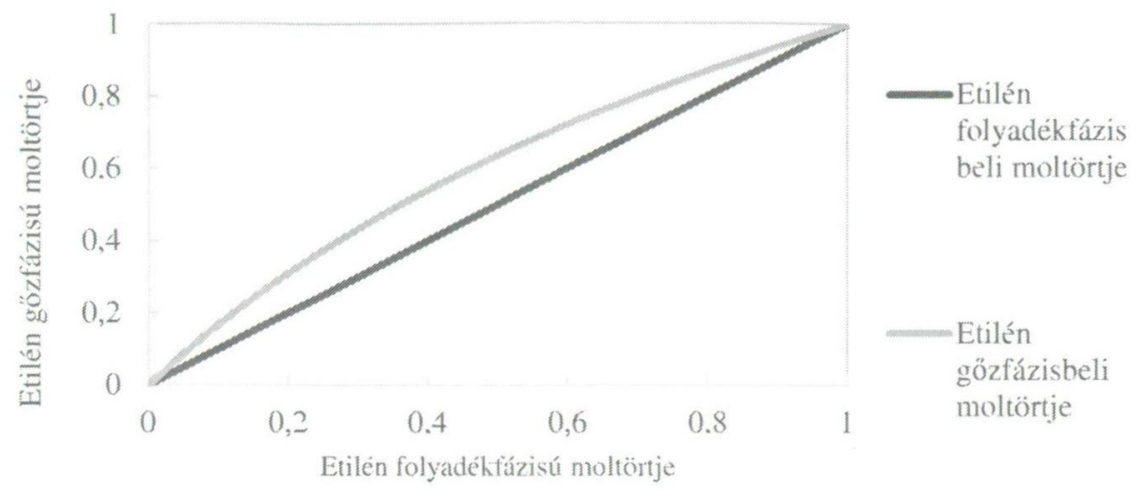

Forrás: A szerző saját szerkesztése. /Kállai V. (2017)

\section{A modell létrehozása}

A folyamat szimulációja Unisim Design (UniSim ${ }^{\circledR}$ Design User Guide) környezetben készült (3. ábra), SRK (Jaubert-Privat, 2010) anyagmodell segítségével.

2. ábra: Etilén-etán szétválasztó kolonna modellje Unisim Design szoftverben

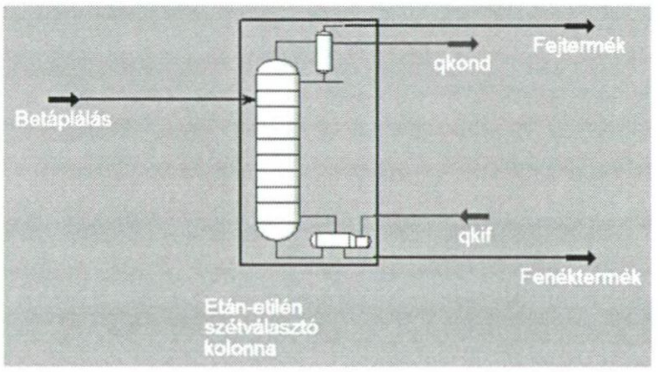

Forrás: A szerző saját szerkesztése. /Kállai V. (2017)

2.1. Kolonna paraméterei

A rektifikáló oszlop 45 darab szitatányérral rendelkezik, amelyek átmérője 2 méter, a tányértávolság 0,4 méter. A betáplálás - a kolonna legfelső tálcájától kezdve a számolást - a negyvenedik tányéron gőz formájában történt az 1. táblázatban közölt paraméterek szerint. 
1. táblázat: Betáplálás adatai

\begin{tabular}{|l|l|}
\hline Betáplálás \\
\hline Hömérséklet $\left[{ }^{\circ} \mathrm{C}\right]$ & $-60,2$ \\
\hline Nyomás [bar] & 6 \\
\hline Mennyiség [kg/h] & 30000 \\
\hline Összetétel [n/n\%] & \\
\hline Etilén & 70 \\
\hline Etán & 30 \\
\hline
\end{tabular}

\subsection{Kihozatali termékek}

A kezdeti modellben a reflux arány 3 , a fejtermék mennyisége $20000 \mathrm{~kg} / \mathrm{h}$, mely technológiai alapadat. A szimuláció során kapott fej- és fenéktermékre vonatkozó adatokat a 2. táblázat tartalmazza.

2. táblázat: Termékek adatai

\begin{tabular}{|c|c|c|c|}
\hline \multicolumn{2}{|l|}{ Fejtermék } & \multicolumn{2}{|l|}{ Fenéktermék } \\
\hline Hömérséklet $\left[{ }^{\circ} \mathrm{C}\right]$ & $-70,92$ & Hőmérséklet $\left[{ }^{\circ} \mathrm{C}\right]$ & $-54,55$ \\
\hline Nyomás [bar] & 5 & Nyomás [bar] & 5 \\
\hline Mennyiség [kg/h] & 20000 & Mennyiség [kg/h] & 10000 \\
\hline Összetétel [n/n\%] & & Összetétel [n/n\%] & \\
\hline Etilén & 99,9975 & Etilén & 5,95 \\
\hline Etán & 0.0025 & Etán & 94.05 \\
\hline
\end{tabular}

\section{Paramétervizsgálat}

A vizsgálat célja megkeresni az optimális értéket arra az esetre, ha maximális fejtermékbeli etilén moltörtet szeretnénk elérni minimális energia-felhasználás mellett. A betáplálás pozíciójának, a reflux aránynak, illetve a nyomásnak, mint paraméternek a hatása került vizsgálatra.

Továbbá megvizsgáltuk azt is, hogy a fejtermék elvárt mennyiségének változtatásával melyik érték esetén érhetünk el közel 100 százalék tisztaságú etilént a fejtermékben.

\subsection{Betáplálás helyének változtatása}

A betáplálás helyének változtatásaiból származó következtetéseket mutatjuk be. A szimulációk alapján megállapítható, hogy a betáplálás helye és a megadott feltételek mellett elérhető legnagyobb etilén koncentráció $(99,9981 \%)$ szempontjából megoldást jelent, ha a 38-39. tálcára történik a szétválasztandó anyagnak a kolonnába történö bevezetése (4. abra).

Az adatokból azt is láthatjuk, hogy ha csak a betáplálás helyének változtatásából származó hatást vizsgáljuk a fejtermék etilénkoncentrációjára, akkor a 30-41 tartományba eső tányérok bármelyikére vezetve a betáp áramot a fejtermékbeli etilén moltört nagyon csekély mértékben fog változni (A tartomány minimuma: 99,991\%). 


\section{4. ábra: Fejtermékbeli etilén tisztaság}

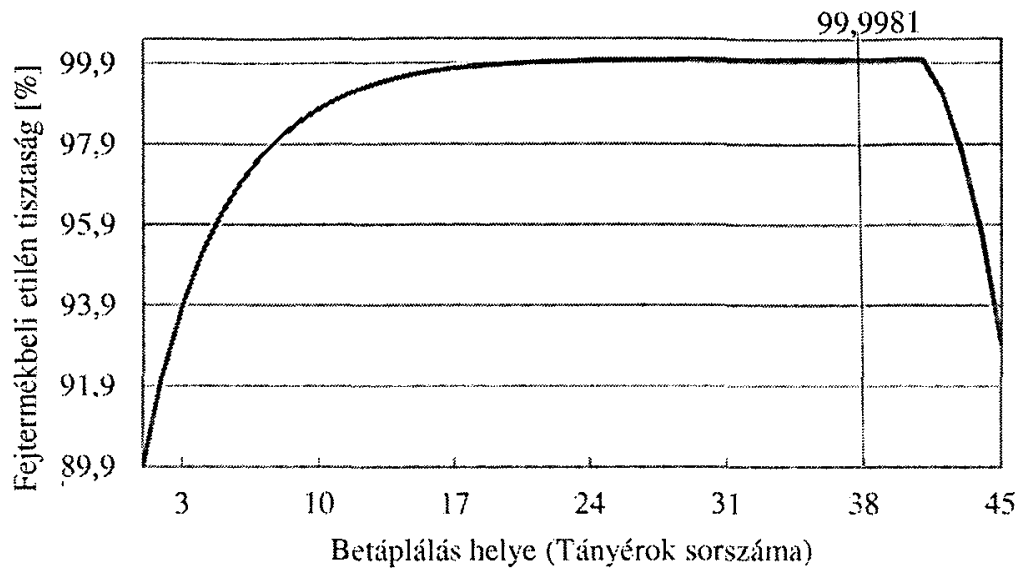

Forrás: A szerző saját szerkesztése. /Kállai V. (2017)

Emiatt szükséges megvizsgálni más tényezőt is, annak érdekében, hogy az optimális megoldást megtaláljuk energetikai szempontból, ugyanis a fejtermék összetétele hatással van a kondenzátor hőigényére.

\subsection{Fejtermék mennyiségének beállítása}

Egy etán-etilén szétválasztó kolonna müködésénél nem csak a fejtermékben mérhető etilén tisztaság a meghatározó, hanem szükséges a mennyiségi összetételre is valamilyen korlátozást bevezetni.

Jelen esetben először meg kell határozni, hogy mennyi a maximális etilén tömege a betáplálási áramból. Moláris arányát tekintve $70 \%$, amelyből meg kell határozni, hogy mennyi a betáplált etilén mennyiség.

ahol:

$$
F_{\text {mol }}=\frac{F_{\mathrm{kg}}}{0,7 \cdot M_{\text {etilén }}+0,3 \cdot M_{\text {etán }}}
$$

$\mathrm{F}_{\text {mol }}=$ a betáplálás moláris mennyisége $[\mathrm{kmol} / \mathrm{h}]$

$\mathrm{F}_{\mathrm{kg}}=$ a betáplálás tömege $[\mathrm{kg} / \mathrm{h}]$

$\mathbf{M}_{\text {etilén }}=$ az etilén moláris tömege $[\mathrm{kg} / \mathrm{kmol}]$

$\mathbf{M}_{\text {etán }}=$ az etán moláris tömege $[\mathrm{kg} / \mathrm{kmol}]$

$$
F_{\text {mol }}=\frac{30000 \frac{\mathrm{kg}}{\mathrm{h}}}{0,7 \cdot 28,05 \frac{\mathrm{kg}}{\mathrm{kmol}}+0,3 \cdot 30,07 \frac{\mathrm{kg}}{\mathrm{kmol}}}=1046,9 \frac{\mathrm{kmol}}{\mathrm{h}}
$$

Ahhoz, hogy a betáp áramban lévő etilén tömegét megkapjuk a kiszámolt értéket meg kell szorozni az etilén moláris tömegével és az arányával: 


$$
\mathrm{F}_{\text {etilén,kg }}=1046,9 \frac{\mathrm{kmol}}{\mathrm{h}} \cdot 0,7 \cdot 28,05 \frac{\mathrm{kg}}{\mathrm{kmol}}=20555,9 \frac{\mathrm{kg}}{\mathrm{h}}
$$

A rendszerben nem valósul meg tökéletes elválasztás, azaz a $20555,9 \mathrm{~kg} / \mathrm{h}$ etilén mennyiségnek nem tudjuk leválasztani a 100\%-át. A fejtermékként távozó anyagáram tömegét ennek függvényében kell meghatározni. Figyelembe kell azt is venni, hogy a fejtermék mennyiségének növelésével nőni fog a kondenzátor és a kiforraló hőigénye.

3. táblázat Fejtermék mennyiségének és etilén moltörtjének változása

\begin{tabular}{|l|l|}
\hline Fejtermék mennyisége $[\mathrm{kg} / \mathrm{h}]$ & Fejtermékbeli etilén moltört \\
\hline 15000 & 0,999986 \\
\hline 20000 & 0,999981 \\
\hline 20300 & 0,999967 \\
\hline 20500 & 0,997607 \\
\hline 21000 & 0,975819 \\
\hline
\end{tabular}

A kihozatali adatokat tekintve (3. táblázat) a $20300 \mathrm{~kg} / \mathrm{h}$ mennyiséget célszerü alkalmazni peremfeltételként a fejtermékre, hiszen ezzel a kívánt tisztaság elérhető úgy, hogy az óránként betáplált etilén 98,74 tömeg\%-a kinyerhető.

\subsection{Nyomás változtatása}

A rektifikáló oszlop paraméterei közül a nyomás is jelentős tényező az optimális müködés szempontjából. Megvizsgálva különböző nyomásértékeknél a kolonna más paramétereit, a szimulációs paramétervizsgálat alapján kimutatható, hogy az etilén moltörtjét tekintve 3-6 bar nyomású betáplálással érhető el az etilénben legtisztább fejtermék.

Mivel a nyomás és a hömérséklet között egyértelmủ kapcsolat van, így a nyomás növelésével csökkenni fog a kolonnához tartozó kiforraló és kondenzátor höigénye (4. táblázat).

4. táblázat: Nyomásváltoztatás hatása

\begin{tabular}{|c|c|c|c|c|}
\hline $\begin{array}{c}\text { Betáp } \\
\text { nyomása } \\
{[\mathrm{bar}]}\end{array}$ & $\begin{array}{c}\text { Betáp } \\
\text { hömérséklete } \\
{\left[{ }^{\circ} \mathrm{C}\right]}\end{array}$ & $\begin{array}{c}\text { Fejtermékbeli } \\
\text { etilén } \\
{[\mathrm{n} / \mathrm{n} \%]}\end{array}$ & $\begin{array}{c}\text { Kiforraló } \\
\text { höigénye } \\
{[\mathrm{kW}]}\end{array}$ & $\begin{array}{c}\text { Kondenzátor } \\
\text { höigénye } \\
{[\mathrm{kW}]}\end{array}$ \\
\hline 1 & $-98,44$ & 100,0000 & 6747 & 8185 \\
\hline 3 & $-76,99$ & 99,9997 & 6344 & 7690 \\
\hline 6 & $-60,2$ & 99,9975 & 5969 & 7234 \\
\hline 8 & $-52,3$ & 99,7469 & 5723 & 6914 \\
\hline 10 & $-45,74$ & 98,6402 & 5336 & 6685 \\
\hline
\end{tabular}

A 4. táblázat alapján megállapítható, hogy a betáp 6 bar nyomáson történő betáplálásával teljesül a 99,99\% etilén tisztaságra vonatkozó követelmény. 
3.4. Reflux arány módosítása

A kolonna jelentős paramétere a kihozatali termékek szempontjából a reflux arány, melynek nagysága szoros kapcsolatban áll a kondenzátor teljesítményének nagyságával. Ha növeljük a reflux arányt, akkor nőni fog a kondenzátor hőigénye is.

\section{5. ábra: Reflux arány hatása a fejtermék etilén tartalmára és a kondenzátor teljesítményére}

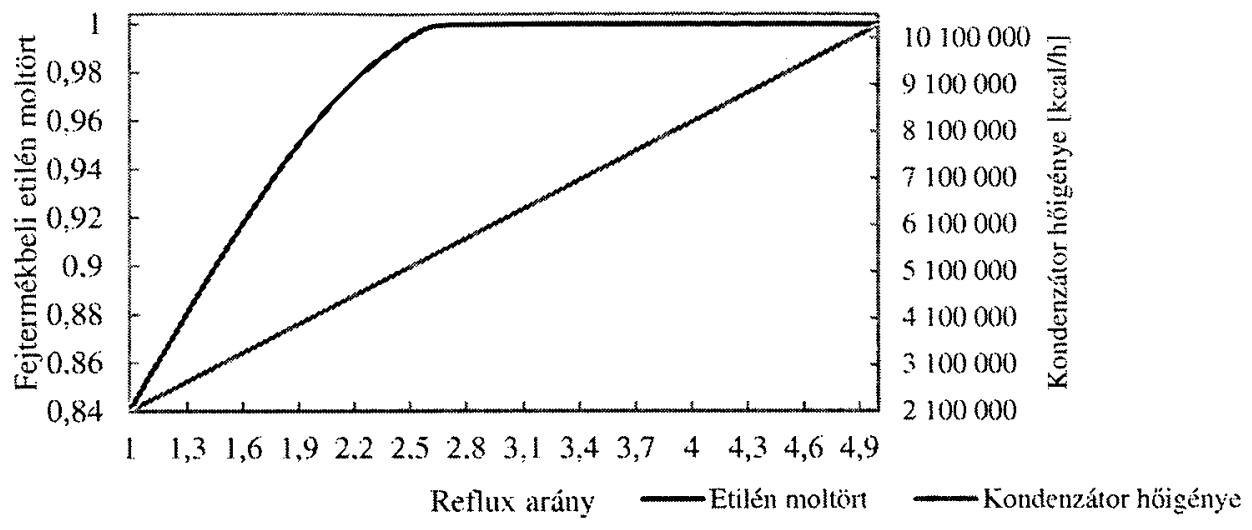

Forrás: A szerző saját szerkesztése. /Kállai V. (2017)

A vizsgálat elején meghatározott elérni kívánt etilén moltört $99,99 \%$ volt, amely már a 2,8 reflux aránnyal is elérhető, így az optimális energiafelhasználás érdekében a reflux arányt erre az értékre ajánlott felvenni. Az 5. ábrán látható, hogy körülbelül a 2,8 reflux aránytól nem nő számottevő mértékben a fejtermékben található etilén koncentráció. Viszont a kondenzátor höigénye és a reflux arány között lineáris kapcsolat van. Minimális etilén moltört változás esetén is nagy ugrások vannak a kondenzátor höigényének nagyságában.

\section{4. Összegzés}

A paramétervizsgálat elvégzése után, beállítva a modellen az optimálisnak meghatározott értékeket, a kolonna az 5. táblázatban feltüntetett adatokkal rendelkezik.

\section{1. táblázat: Optimális kolonna paraméterek}

\begin{tabular}{|l|l|}
\hline Betáplálás helye & 38 . tányér \\
\hline Betáplálás nyomása & 6 bar \\
\hline Reflux arány & 2,8 \\
\hline Fejtermék mennyisége & $20300 \mathrm{~kg} / \mathrm{h}$ \\
\hline Fejtermékbeli etilén mennyiség & $20298 \mathrm{~kg} / \mathrm{h}$ \\
\hline Fejtermékbeli etilén moltört & $99,9907 \%$ \\
\hline
\end{tabular}


A szimulációk alapján kijelenthetö, hogy egy rektifikáló oszlop müködését számos paraméter befolyásolja, amelyek változtatásával hatékonyabb müködés biztosítható. A módosításokat úgy célszerü végrehajtani, hogy nem hagyjuk figyelmen kívül, hogy ezen tényezők egymással szoros kapcsolatban állnak. A bemutatott paramétervizsgálat központi témájában álló etán-etilén szétválasztó kolonna müködtetésénél legfontosabb szempont az etilénben leginkább gazdag fejtermék kinyerése, azon feltételek mellett, hogy a fenéktermékben távozó etilén mennyisége minimális legyen, a hőcserélők hőszükségleteinek viszonylag alacsony értéke mellett.

\section{Köszönetnyilvánítás}

"A cikkben/elöadásban/tanulmányban ismertetett kutató munka az EFOP-3.6.1-162016-00011 jelü „Fiatalodó és Megújuló Egyetem - Innovatív Tudásváros - a Miskolci Egyetem intelligens szakosodást szolgáló intézményi fejlesztése" projekt részeként - a Széchenyi 2020 keretében - az Európai Unió támogatásával, az Európai Szociális Alap társfinanszírozásával valósul meg."

\section{Irodalomjegyzék}

Benali, M., Aydin, B. (2010): Ethane/ethylene and propane/propylene separation in hybrid membrane distillation systems: Optimization and economic analysis. Separation and Purification Technology, 73 (3): 377-390.

Fonyó, Z., Fábry G. (1998): Vegyipari müvelettani alapismeretek. Nemzeti Tankönyvkiadó Rt., Budapest.

Jaubert, J. N., Privat, R. (2010): Relationship between the binary interaction parameters $\left(\mathrm{k}_{\mathrm{ij}}\right)$ of the Peng-Robinson and those of the Soave-Redlich-Kwong equations of state: Application to the definition of the PR2SRK model. Fluid Phase Equilibria, 295 (1): 26-37.

Perry, R. H., Green, D. W., Maloney, J. O., (1997): Perry's Chemical Engineers' Handbook. 7th edition, McGraw-Hill.

Soave, G. S., Gamba, S., Pellegrini, L. A., Bonomi, S. (2006): Feed-splitting technique in cryogenic distillation. Ind. Eng. Chem. Res., 45 (16): 5761-5765.

UniSim ${ }^{\circledR}$ Design User Guide 